\title{
Absorción acústica de cortinas textiles en función del vuelo
}

\section{The acoustic absorption of textile curtains on the function of the fullness}

\author{
R. del Rey(*), J. Alba(*), M. Blanes(**), B. Marco(**)
}

\section{RESUMEN}

Los materiales absorbentes acústicos se aplican para reducir los niveles de ruido en una sala. También se usan para ajustar el tiempo de reverberación de un recinto al uso acústico para el que está diseñado. Existen salas de uso múltiple para conferencias, conciertos, cines, etc. En este caso, los materiales absorbentes acústicos deberían cambiarse en función del uso. Las cortinas pueden ser un elemento sencillo para modificar las condiciones acústicas de una sala en función del uso. En este trabajo se presenta un estudio de la absorción acústica de diferentes cortinas en condiciones reales de colocación. El estudio se realiza en cámara reverberante. En él se tienen en cuenta diferentes telas. También se tienen en cuenta diferentes plenums de aire y diferentes vuelos de la tela para hacer el fruncido. En este trabajo se compara la absorción acústica de distintas posibilidades de telas, plenums y vuelos. Se observa en los resultados el buen comportamiento acústico de estos sistemas.

Palabras clave: coeficiente absorción acústica; cortinas acústicas; cámara reverberante; textiles en edificación.

\begin{abstract}
Acoustic absorbing materials are applied to reduce noise levels in a room. They are also used to adjust the reverberation time an acoustic enclosure to use for which it's designed. There are multi-purpose rooms for conferences, concerts, cinemas, etc. In this case, the acoustic absorbent materials should be changed according to use. Curtains can be an easy way to modify the acoustics of a room based on usage. This paper presents a study of the acoustic absorption of different curtains under actual placement. The study was performed in a reverberant chamber. It takes into account different textiles. It also takes into account different air plenums and different fullness to pucker. It can be seen in the results, good acoustic behavior of such systems. The acoustic absorption of different fabrics, air plenums and plicate of textiles (fullness) are compared in this work. The good acoustic behaviour of these systems is observed in the results.
\end{abstract}

Keywords: acoustic absorption; textile absorbent; acoustic curtains; reverberant chamber; soft porous media.

\footnotetext{
(*) Universitat Politécnica de València, Gandía (València, España).

(**) AITEX. Instituto Tecnológico del Textil, Alcoy (Alicante, España).
} 


\section{INTRODUCCIÓN}

Los materiales absorbentes acústicos son un método efectivo y reconocido para reducir el ruido molesto dentro de un recinto o para ajustar las condiciones acústicas de un cine, de un auditorio, una sala de conciertos, etc.

El ruido se contempla a nivel mundial como uno de los problemas ambientales importantes, tal y como se muestra en los estudios de la OMS (1). Según la OMS, el ruido excesivo daña seriamente la salud humana e interfiere con las actividades cotidianas de las personas en la escuela, en el trabajo, en casa y en el tiempo libre. El ruido puede perturbar el sueño, causar efectos cardiovasculares y psicofisiológicos, reducir el rendimiento, provocar molestias y cambios en el comportamiento social. Este hecho justifica que en los últimos años haya habido un gran desarrollo legislativo y diferentes países han publicado distintas normativas para disminuir el ruido en la edificación (2). En estas normativas se exige, entre otras cuestiones, la reducción del ruido reverberante excesivo dentro de las viviendas, y en particular, en bares y restaurantes, aulas, salas de conferencias, etc. El uso de materiales absorbentes acústicos, en diferentes formas de colocación y distintas combinaciones es fundamental para ello.

Se pueden encontrar datos de la absorción acústica de materiales comúnmente utilizados en el catálogo de Elementos constructivos del Código Técnico de la Edificación (3), o en páginas web de los fabricantes. Además, dado el interés que genera la obtención de nuevos productos, sobre todo aquellos que se basan en reciclados y fibras naturales, están apareciendo datos sobre la absorción acústica de nuevos materiales como las espumas de aluminio en Navacerrada et al (4), de lanas de kenaf en Ramis et al (5), de lanas de poliéster (PET) fabricadas con restos botellas de plástico en Del Rey et al (6), espumas recicladas en Del Rey et al (7) o paneles de carrizo, una planta parecida a la caña común en Díaz et al (8). En los casos donde únicamente se necesita absorción acústica para reducir el ruido reverberante excesivo, es suficiente con estos materiales.

Sin embargo, existen otros casos donde la calidad acústica requerida depende de la adecuada combinación de materiales absorbentes acústicos en función de los usos del recinto: conferencias, música de cámara, orquesta de cuerda, banda de música, proyección de películas, etc. Para estos niveles de calidad acústica, es necesaria la elección adecuada de materiales y su disposición, tal y como se trata desde hace años en diferentes libros $(9,10,11)$ y artículos $(12,13)$. En estas referencias se justifica que es conveniente cierta movilidad de los materiales absorbentes, que permitan adaptar la absorción acústica necesaria al uso acústico que se pretende. En

\section{INTRODUCCIÓN}

Acoustic absorbent materials are an effective and recognized method to reduce unwanted noise within a room or to adjust the acoustics of a cinema, an auditorium, a concert hall, etc.

Noise is contemplated globally as one of the important environmental problems, as shown in studies conducted by the World Health Organization (WHO)(1). According to the WHO, excessive noise seriously harms human health and interferes with the daily activities of people at school, work, home and during their free time. Noise can disturb sleep, cause cardiovascular and psychophysiological effects, reduce performance and cause inconveniences and changes in social behavior. This fact justifies the point that in recent years there has been a dramatic legislative development and different countries have issued various regulations to reduce noise in buildings (2). In these regulations it is required, among other things, to reduce excessive reverberant noise inside housing, particularly in bars and restaurants, classrooms, conference rooms, etc. The use of acoustic absorbent materials in different ways and combinations of placement is critical to this.

Details of the acoustic absorption of materials commonly used can be found in the catalog of building elements of the Technical Building Code (3) and manufacturers' web pages. Furthermore, because of the interest generated by the development of new products, especially those based on recycled and natural fibers, there is emerging acoustic absorption data on new materials such as aluminum foams presented in Navacerrada et al. (4), kenaf wool referenced in Ramis et al. (5), polyester wool (PET) made of plastic bottles remains as said in Del Rey et al. (6), recycled foam shown in Del Rey et al.(7) or carrizo panels, which is a common reed-like plant that appears in Díaz et al. (8). In cases where only acoustic absorption is needed to reduce excessive reverberant noise such materials are sufficient.

However, there are other cases where the required acoustic quality depends on the right combination of acoustic absorbing materials according to the uses of the room: conferences, chamber music, string orchestras, band music, film shows, etc. For these levels of sound quality, it is necessary to make the appropriate choice of materials and their disposition as has been discussed for many years in different books $(9,10,11)$ and articles $(12,13)$. In these references it is justified that the absorbent material mobility is desirable for adapting the necessary acoustic absorption to the intended acoustic use. In such cases, one of the limitations which can 
esos casos, una de las limitaciones que pueden plantear los materiales absorbentes anteriormente citados, es que normalmente ocupan posiciones fijas dentro del recinto donde se quiere acondicionar, dejando pocas opciones al cambio.

Una alternativa puede ser el uso de cortinas textiles. El uso de cortinas textiles como elementos absorbentes acústicos aparece desde hace tiempo en trabajos como Peutz (14). Rein Pirn (15) propone un trabajo sobre cortinas retráctiles para modificar la acústica de una sala. Houtsma et al (13) trata el cambio en los parámetros de calidad de una sala en función de los cambios en las cortinas. Yamada et al (16) realiza un análisis numérico de un cortina colgada. Soedel et al (17) estudian la distribución de modos propios de las cortinas.

Para poder valorar si un textil utilizado como cortina presenta absorción acústica se puede utilizar la norma ISO 10534-2:1998 (18). Esta norma permite conocer los valores del coeficiente de absorción en incidencia normal. Ejemplos de estos estudios se encuentran por ejemplo en Chen and Jiang (19). En Yang et al (20) se muestra un trabajo sobre los cambios que se producen en la absorción sonora variando las fibras textiles. También es muy interesante el estudio de Pieren (21) que tiene en cuenta el plenum que se forma detrás de la tela. Sin embargo, los datos presentados en estos trabajos no dan suficiente información para poder aplicar los resultados directamente a una sala. Según las referencias citadas (9-13) es necesario tener datos de absorción acústica medidos en cámara reverberante según la norma ISO 354:2003 (22) o similares.

En este trabajo se realiza un estudio sobre la absorción acústica de cortinas en cámara reverberante. En este estudio se tienen en cuenta las condiciones de montaje de la cortina. Por ello se plantean diferentes plenums y distintos vuelos, analizando la influencia de estos cambios en los resultados finales de la absorción sonora.

\section{DESCRIPCIÓN DEL PROGRAMA DE EXPERIENCIAS}

En primer lugar, debe elegirse la tela a partir de la cual se confeccionará la cortina. El tipo de tela es $100 \%$ poliéster (PES) e ignífuga clase 1 o superior según UNE-EN 13773:2003 (23), como las que de forma habitual se utilizan en el ámbito del textil. En la Figura 1 pueden observarse algunas de las telas objeto de estudio.

En segundo lugar, las condiciones de montaje de las cortinas deben ser las mismas que en su uso habitual. Es por ello que se propone el uso de rieles convencionales. En este caso, se combinan los textiles en soportes present the absorbent materials referred is normally in fixed positions inside the room where it must be placed, leaving few options for change.

An alternative may be the use of textile curtains. The use of textile curtains like acoustic absorbent elements have appeared for a long time in studies like Peutz (14). Pirn (15) proposes a study about retracTable curtains to change the room acoustics. Houtsma et al (13) treat the change in the quality parameters of a room according to the changes in the draper. Yamada et al (16) perform a numerical analysis of a hanging curtain. Soedel et al (17) studied the distribution of unique ways of the draper.

To evaluate whether a textile used as curtain presents acoustic absorption the standard ISO 10534-2:1998 can be used (18). This standard allows understanding of the values of the absorption coefficient at normal incidence. Examples of these studies are found in Chen and Jiang (19). Yang et al (20) present a study about the changes that occur in the sound absorption when the textile fibers are modified. It is also interesting to look at the Pieren (21) research that considers the plenum that forms behind the textile. However, the data presented in these studies do not give enough information to apply the results directly to a room. According to cited references (9-13) is necessary to obtain data of the acoustic absorption measured in a reverberant chamber according to standard ISO 354:2003 (22) or similar.

In this work an acoustic absorption study of curtains in a reverberant chamber is realized. In this study the installation conditions of the curtain are considered. For this reason different plenums and various degrees of fullness are presented analyzing the influence of these changes on the final results of sound absorption.

\section{DESCRIPTION OF THE EXPERIENCES PROGRAM}

The experience parts of the following hypotheses. Firstly, the cloth must be chosen from which the curtain is to be drawn. The type of fabric must be $100 \%$ polyester (PES) and fireproof class C1 or higher according to UNE-EN 13773:2003 (23), such as those usually used in the textile field (Figure 1).

Secondly, the installation conditions of the curtain should be the same as in normal use. This is the reason why using conventional rails is proposed. In this case, the textiles are combined in standard rails which allow three 


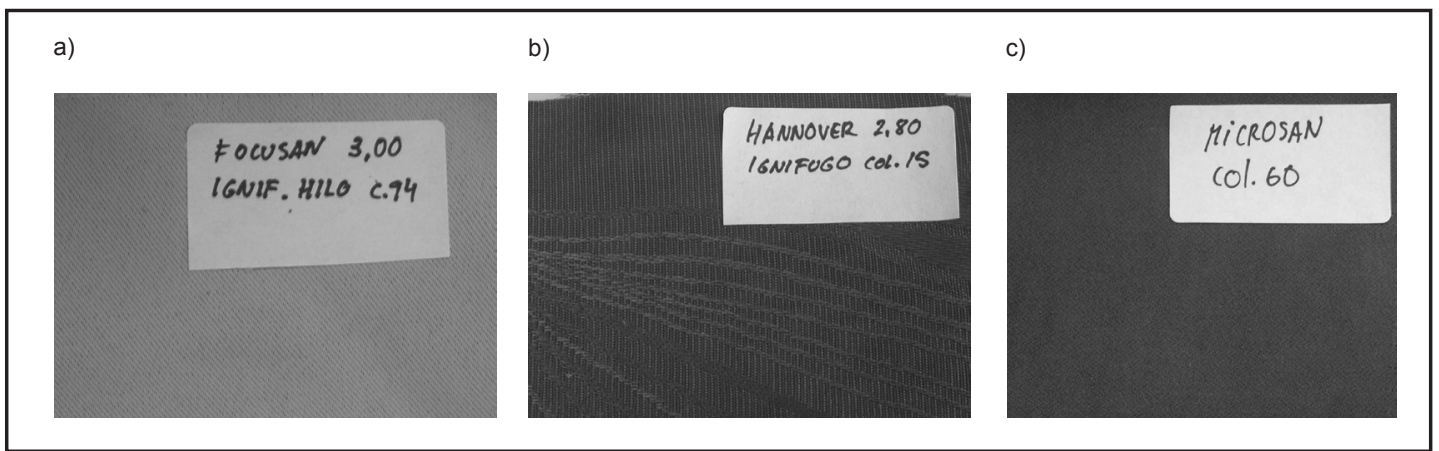

Figura 1. Algunos de los tejidos elegidos para el estudio.

Figure 1. Textiles chosen for study.

estándar que permite tres posibles distancias respecto a la superficie a cubrir, $8,5 \mathrm{~cm}, 14,5 \mathrm{~cm}$ y $20,5 \mathrm{~cm}$, esto es plenums de $8,5,14,5$ y $20,5 \mathrm{~cm}$. Además, para mantener dichas condiciones se combinan diferentes vuelos de cortina (expresados en $\%$ ), siendo $0 \%$, cortina sin vuelo (la cortina se vería lisa), $100 \%$ cortina con el doble de tela para realizar el fruncido, $150 \%$, cortina con 2,5 veces más de tela y $200 \%$ cortina con el triple de tela para el fruncido. En la Figura 2 se muestra un detalle de los rieles y de la colocación de los textiles. different distances relative to the surface to be covered, $8.5 \mathrm{~cm}, 14.5 \mathrm{~cm}$ and $20.5 \mathrm{~cm}$, these distances correspond with the air plenums used in the study. Furthermore, to keep these conditions different drapery fullness (expressed in \%), being 0\%, without curtain fullness (the draper would look flat), 100\% curtain has double fabric for puckering, 150\%, draper with 2.5 times more textile and $200 \%$, curtain with three times more tissue for shirring are combined. Figure 2 shows a detail of the rails and the placement of the textile.

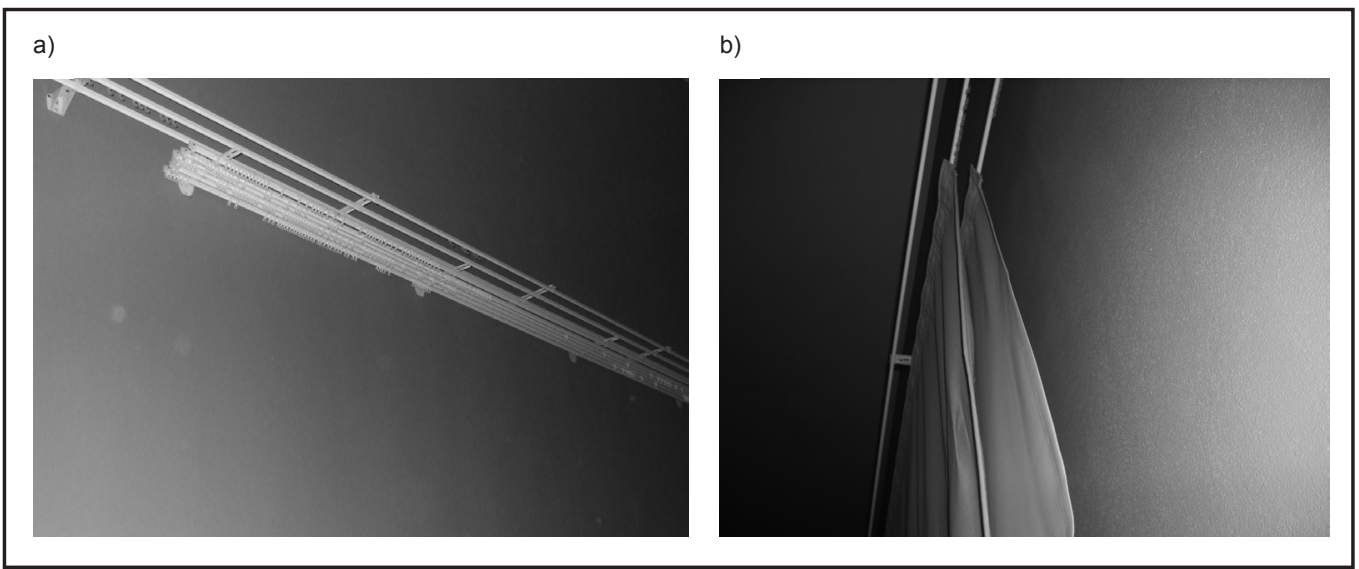

Figura 2. Detalles de rieles y colocación.

Figure 2. Rails details and placement.

Para simplificar el número de ensayos en cámara reverberante se propone la medición de la resistividad al flujo de las telas propuestas. Este parámetro representa la oposición al paso de aire que presenta el material por unidad de longitud. Si el valor es elevado (superior a $100 \mathrm{kPas} / \mathrm{m}^{2}$ ) podemos suponer que apenas hay paso del aire a través del material. La resistividad al flujo puede determinarse según la norma ISO 9053:1991 (24). Dada la complejidad de ensayo según esta norma, es común utilizar métodos alternativos. Para este trabajo se sigue el método indirecto propuesto por Ingard and Dear (25). En la Tabla 1 se resumen los resultados obtenidos, junto con otros datos de interés de las telas.
To simplify the number of tests the measuring of the flow resistivity of the proposed fabrics is suggested. This parameter represents the opposition to the airflow that presents the material per unit length. If the value is high (higher than $100 \mathrm{kPas} / \mathrm{m}^{2}$ ) it can be assumed that there is little air flow through the material. The flow resistivity can be determined according to standard ISO 9053:1991 (24). Because of the complexity of testing under this standard, it is common to use alternative methods. For this work the indirect method proposed by Ingard and Dear (25) has been followed. Table 1 summarizes the results, along with other relevant details of the fabrics. It can be seen that all the fabrics have a flow resistance 
Tabla 1 / Table 1

Datos técnicos de las telas.

Technical data of textile.

\begin{tabular}{|c|c|c|c|}
\hline Telas / Textile & Espesor / Thickness $\mathbf{( c m})$ & Densidad / Density $\mathbf{( g / \mathbf { m } ^ { 2 } )}$ & Resistividad al flujo / Flow resistivity $\left(\mathbf{k P a s} / \mathbf{m}^{2}\right)$ \\
\hline T1 & 0.06 & 230 & 237 \\
\hline T2 & 0.02 & 300 & 719 \\
\hline T3 & 0.03 & 95 & 640 \\
\hline T4 & 0.05 & 200 & 484 \\
\hline T5 & 0.05 & 200 & 450 \\
\hline T6 & 0.10 & 300 & 455 \\
\hline T7 & 0.06 & 250 & 625 \\
\hline
\end{tabular}

Puede verse cómo todas las telas tienen una resistividad al flujo superior a $100 \mathrm{kPas} / \mathrm{m}^{2}$.

A partir del valor de la resistividad al flujo que presentan las distintas telas que conforman las cortinas, éstas pueden considerarse como capas impermeables del sonido, esto es, actuarán como membranas en un sistema que combina, gracias al plenum de aire existente entre tela y pared, distintas formas de absorción del sonido (26).

\section{RESULTADOS DE ENSAYOS EN CÁMARA REVERBERANTE}

Se propone un programa de experiencias de ensayos en la cámara reverberante de la Escuela Politécnica Superior de Gandia (27) según norma ISO 354:2003 (22). De la Tabla 1 se eligen tres telas de cortina ( $T 1, T 2$ y $T 7)$ para realizar todos los ensayos propuestos, que se corresponden con las de menor, mayor e intermedio valor de resistividad al flujo. Se diseña una superficie de ensayo vertical de $11,4 \mathrm{~m}^{2}$, donde se han distribuido $2,8 \mathrm{~m}$ en vertical y $4 \mathrm{~m}$ en horizontal, para garantizar las mismas condiciones en todos los ensayos. En la Figura 3 se muestran fotografías del montaje. higher than $100 \mathrm{kPas} / \mathrm{m}^{2}$. The way in which all textiles have a high flow resistivity can be seen

From the flow resistance value that the fabrics shown, the curtains can be considered as soundproof layers, it means that they will act as membranes in a system that combines different sound absorption ways, thanks to the air plenum between the curtain and the wall (26).

\section{TESTING IN A REVERBERANT CHAMBER}

Testing program experiences in the reverberant chamber of the Polytechnic School Gandia (27) according standard ISO 354:2003 (22) is proposed. From Table 1 three curtain fabrics (T1 T2, and T7) to perform all tests proposed which correspond to the lowest, intermediate and highest flow resistivity are chosen. A vertical test surface is designed of $11.4 \mathrm{~m}^{2}$, which has been distributed $2.8 \mathrm{~m}$ vertically and $4 m$ horizontally to be guaranteed the same conditions in all tests. Figure 3 presents photographs of the mounting procedure.

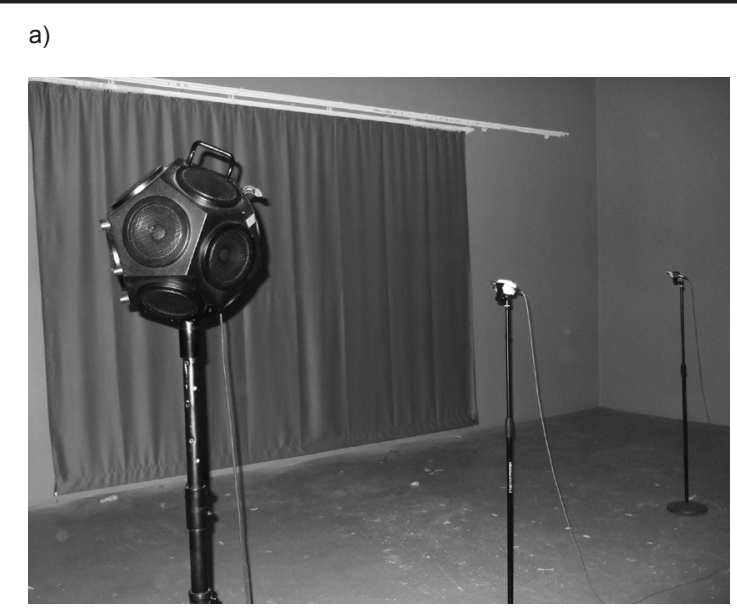

b)

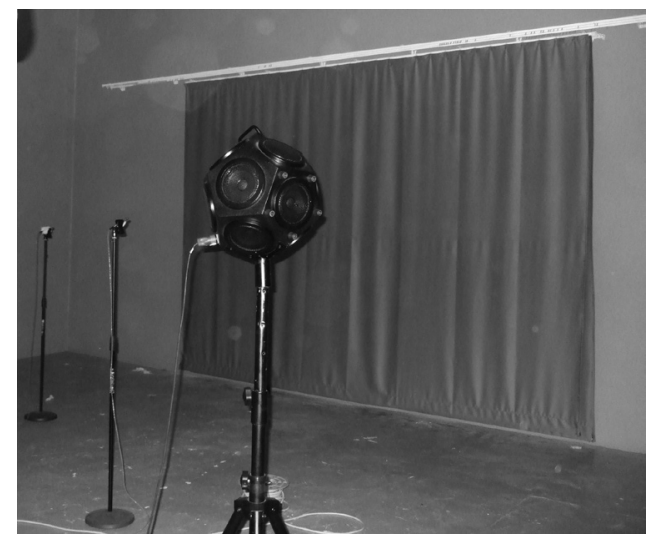

Figura 3. Imágenes del montaje de ensayo en cámara reverberante.

Figure 3. Mounting procedure photographs (reverberant chamber). 
En la Figura 4 se muestran los resultados de la tela 1 (T1) con un plenum de $8,5 \mathrm{~cm}$ y vuelos de $0 \%, 100 \%$, $150 \%$ y $200 \%$. Puede observarse cómo aumenta la absorción acústica al aumentar el vuelo, aunque a partir de $100 \%$ de vuelo el aumento del valor de la absorción es menos significativo. En la Figura 5 los resultados para un plenum de $14,5 \mathrm{~cm}$. En la Figura 6 se muestran los resultados de la tela 2 (T2) con un plenum de $14,5 \mathrm{~cm}$ y en la Figura 7 con un plenum de $20,5 \mathrm{~cm}$. Para las Figuras 5 a 7 se puede realizar el mismo comentario
Figure 4 shows the results of textile 1 (T1) with a plenum of $8.5 \mathrm{~cm}$ and $0 \%, 100 \%, 150 \%$ and $200 \%$ fullness. The way in which the acoustic absorption increases with increasing fullness can be seen, although since the 100\% increase in the value the absorption is less significant. Figure 5 presents the results for a plenum of $14.5 \mathrm{~cm}$. In Figures 6 and 7 the results for fabric 2 (T2) with a plenum 14.5 and $20.5 \mathrm{~cm}$, respectively, are presented. Figures 5 through 7 the same comment as Figure 4 can be applied. It is remarkable that in the case of $T 1$ and $14.5 \mathrm{~cm}$ of air

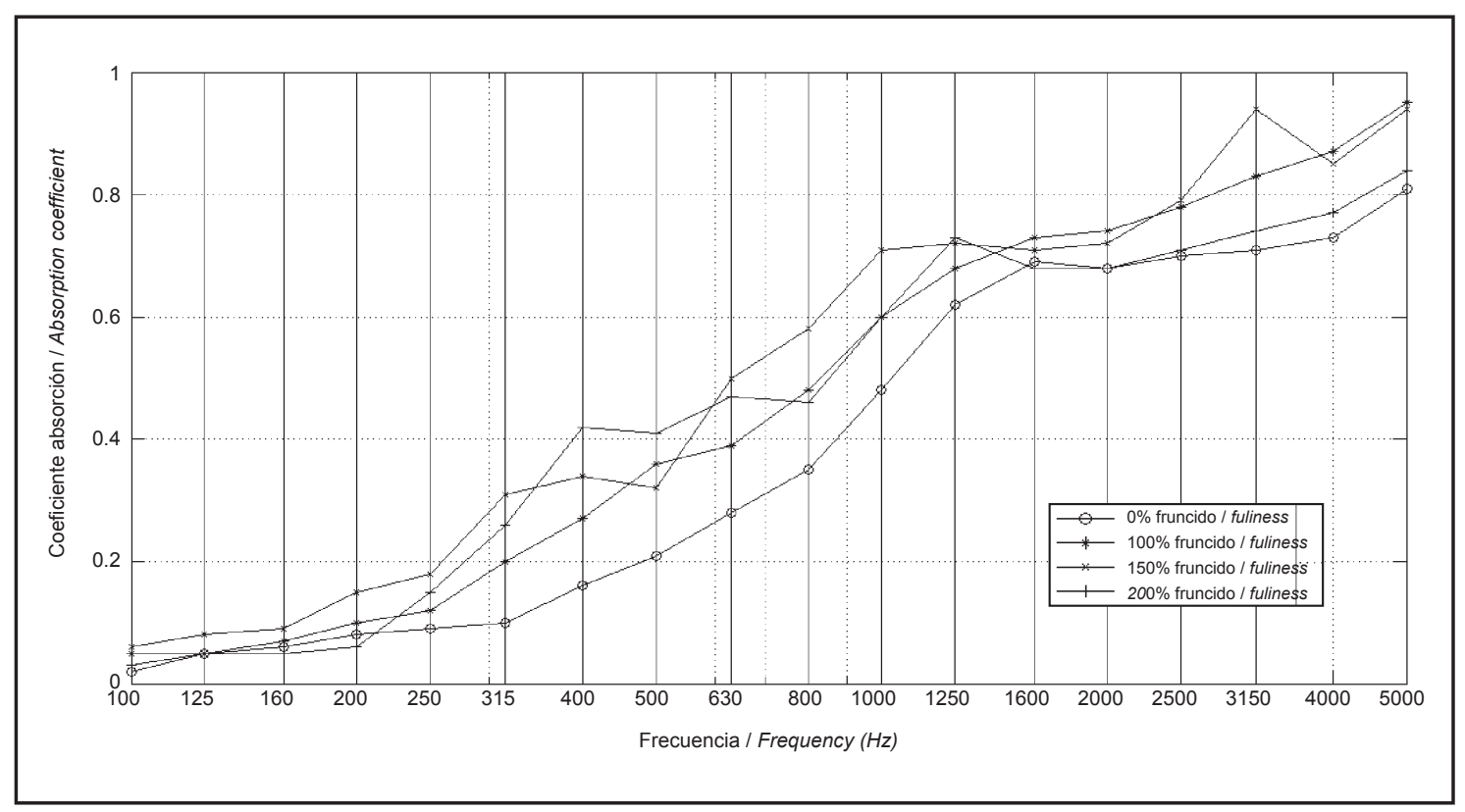

Figura 4. T1 con plenum de $8,5 \mathrm{~cm}$.

Figure 4. $T 1$ with a plenum of $8.5 \mathrm{~cm}$.

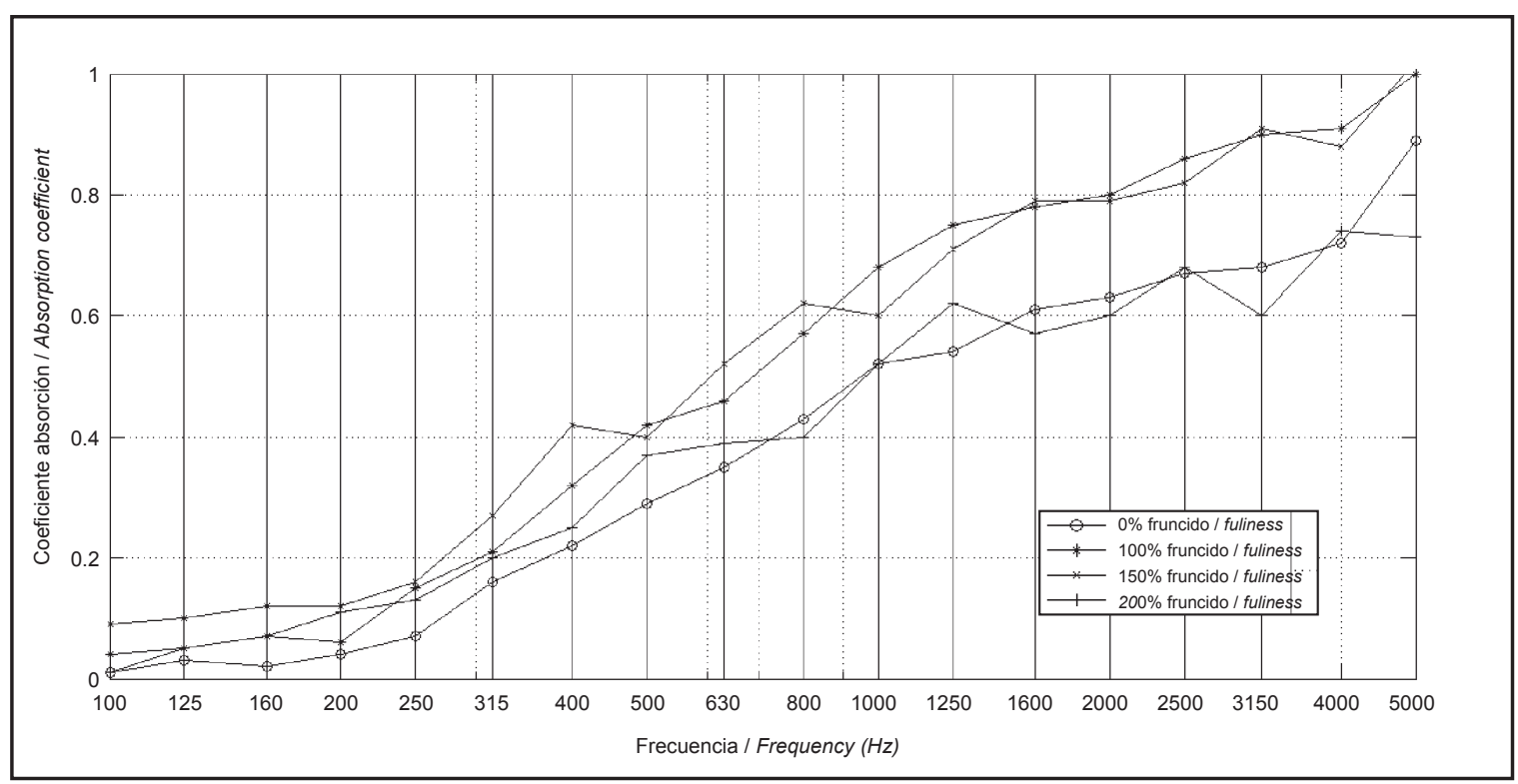

Figura 5 . T1 con plenum de $14,5 \mathrm{~cm}$.

Figure 5. $T 1$ with a plenum of $14.5 \mathrm{~cm}$. 
que con la Figura 4. Es conveniente destacar que en el caso de $\mathrm{T} 1 \mathrm{y}$ plenum de $14,5 \mathrm{~cm}$, los vuelos de $0 \%$ y $200 \%$, casos extremos, presentan valores del coeficiente de absorción muy similares (Figura 5). En la Figura 8 se comparan ambas telas para $14,5 \mathrm{~cm}$ de plenum. Puede observarse cómo los resultados son muy similares para $0 \%$ y $100 \%$ de vuelo, puesto que según la norma de ensayo podemos tener tolerancias de 0,05. A partir de $100 \%$ de vuelo, los resultados empiezan a diferir. plenum, the fullness of limit cases $0 \%$ and $200 \%$, show very similar values of the absorption coefficient (Figure 5). Figure 8 compares the two fabrics to $14.5 \mathrm{~cm}$ plenum, where it can be seen that the results are very similar for $0 \%$ and $100 \%$ fullness, since according to the test standard they can have tolerances of 0.05 . Since $100 \%$ fullness, results begin to be different.

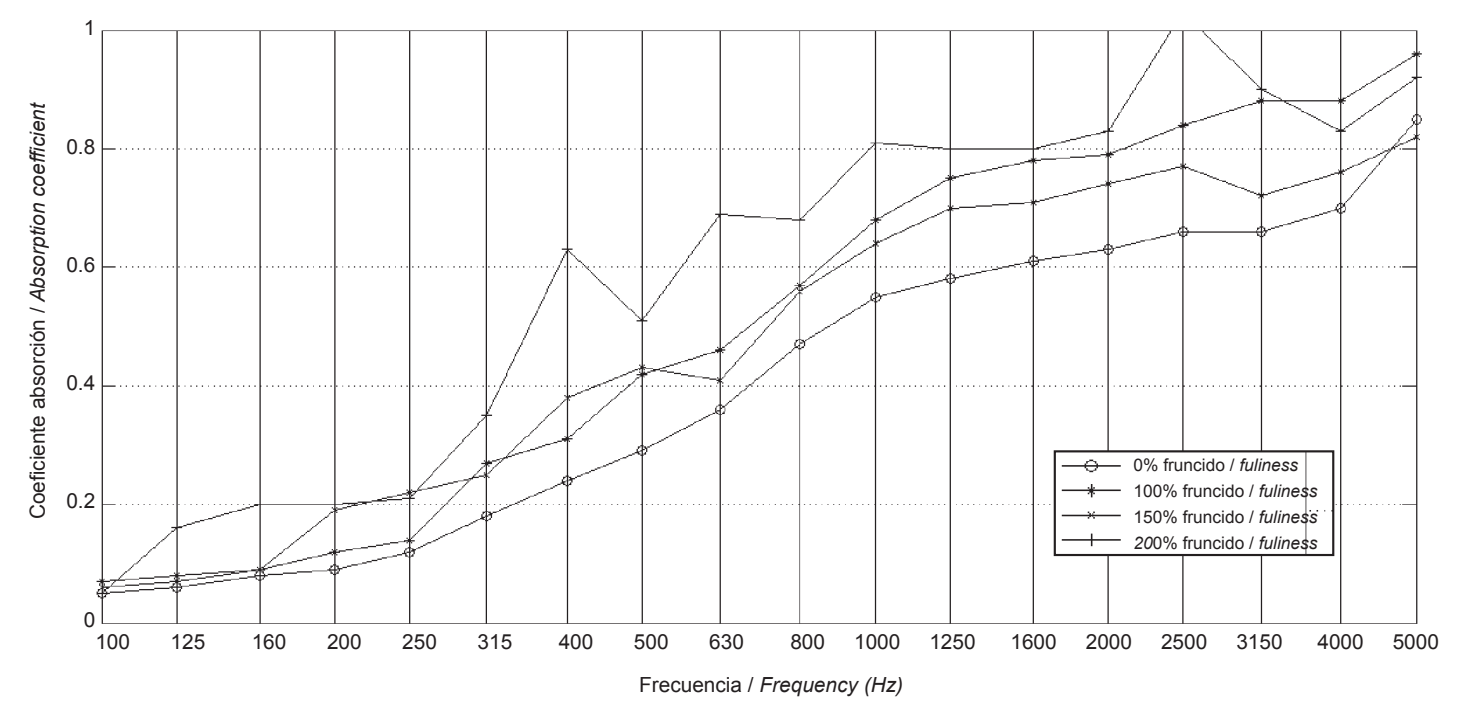

Figura 6. T2 con plenum de $14,5 \mathrm{~cm}$.

Figure 6. T2 with a plenum of $14.5 \mathrm{~cm}$.

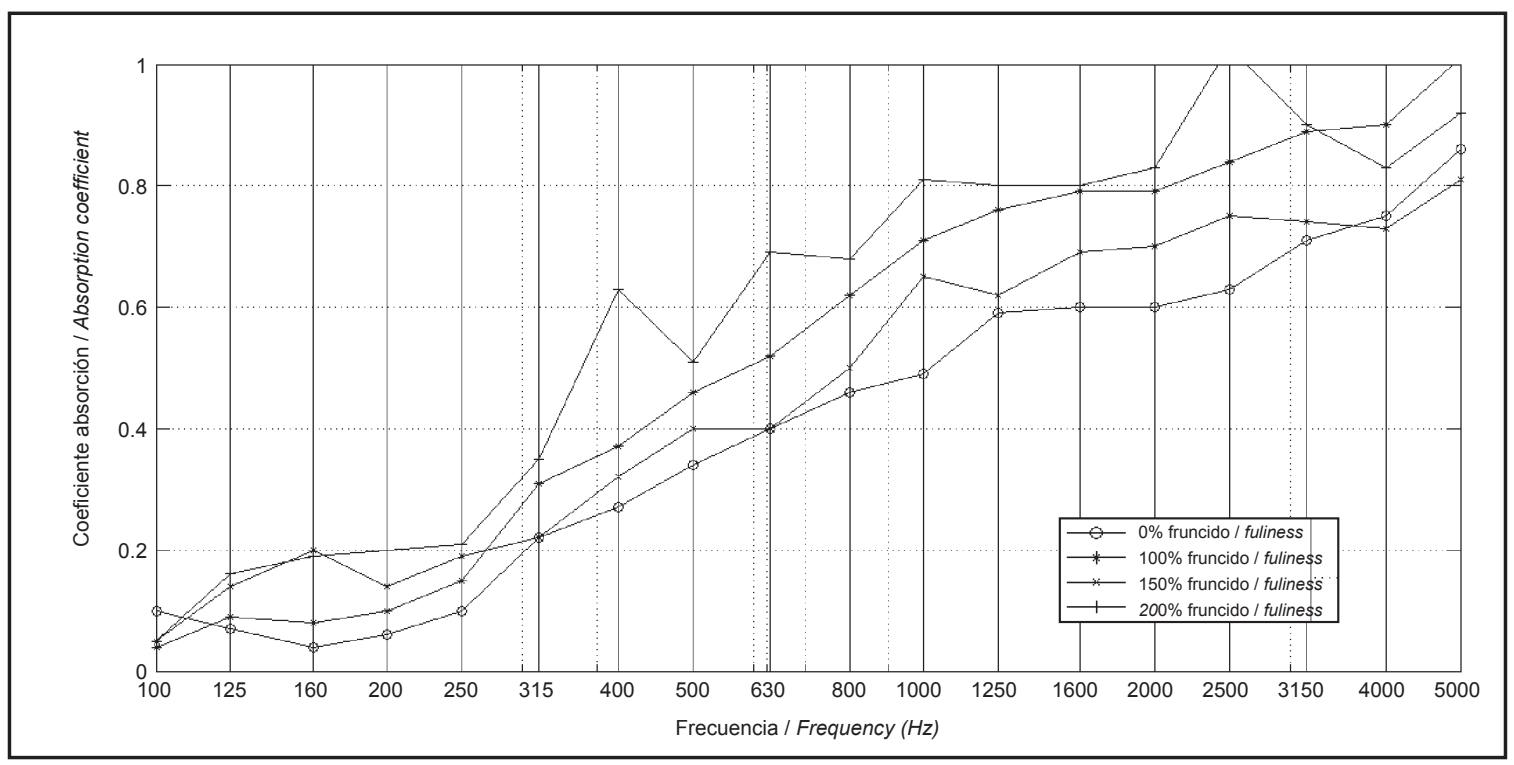

Figura 7. T2 con plenum de $20,5 \mathrm{~cm}$.

Figure 7. $T 2$ with a plenum of $20.5 \mathrm{~cm}$. 


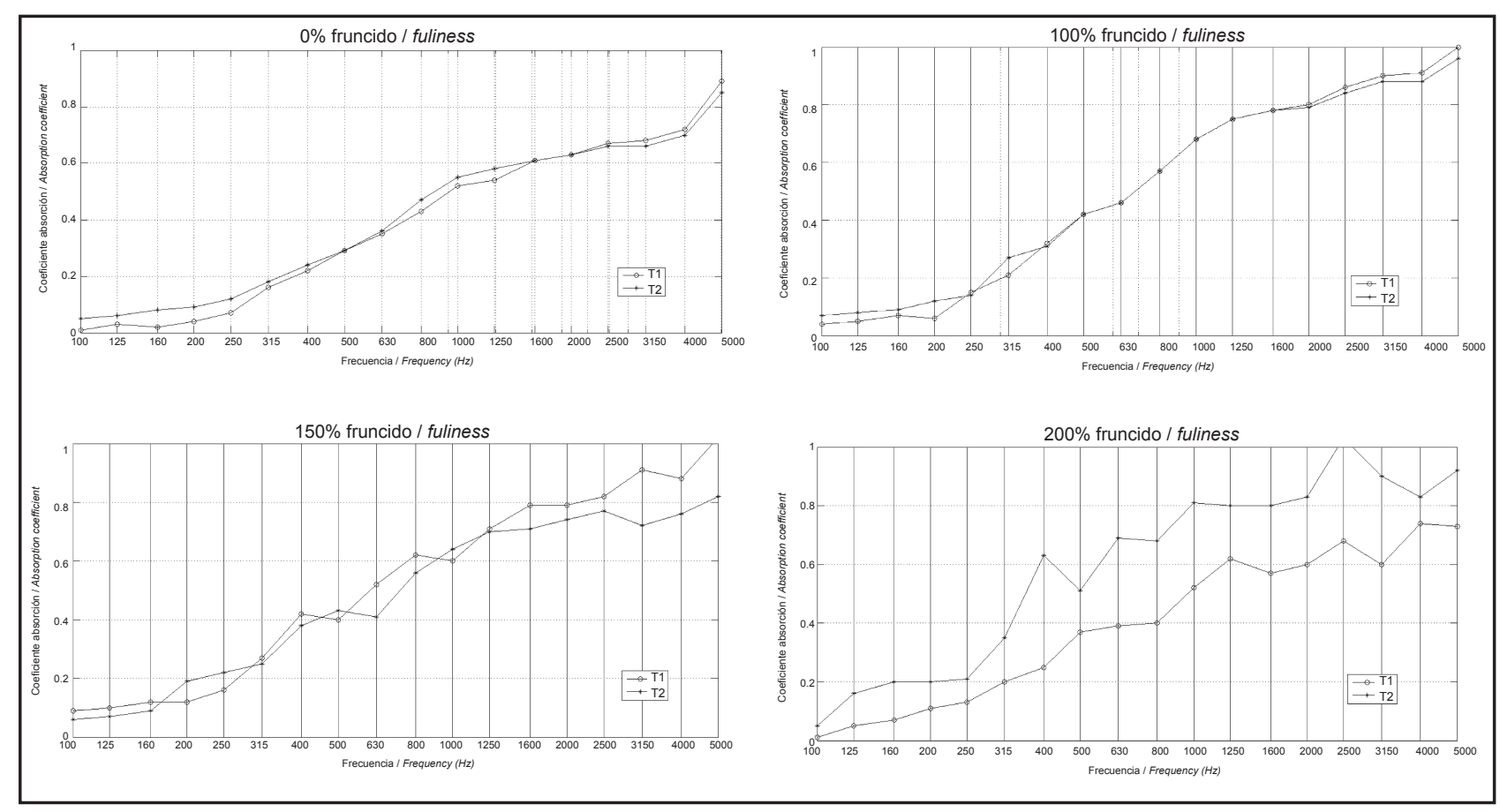

Figura 8. Comparativa de las dos telas ( $\mathrm{T} 1 \mathrm{y} \mathrm{T} 2$ ) con plenum de $14,5 \mathrm{~cm}$.

Figure 8. Comparison of the two textiles (T1 and T2) with a plenum of $14.5 \mathrm{~cm}$.

Como se puede observar en las Figuras, los resultados para el $100 \%$ de vuelo mejoran la absorción acústica respecto al $0 \%$ de vuelo. Además, según se muestra en la Figura 8, no hay diferencias notables entre las dos telas mostradas para vuelos de $0 \%$ y $100 \%$. Estas dos telas, tal y como queda reflejado en la Tabla 1 presentan valores extremos de resistencia al flujo. Es por esto que se decide comparar con una tela que presente un valor intermedio de resistencia al flujo dentro del conjunto de
As can be seen in the Figures, the results for $100 \%$ fullness improve the acoustic absorption compared to $0 \%$. Furthermore, as presented in Figure 8, there are no Table differences between the two textiles shown for $0 \%$ and $100 \%$ fullness. These two fabrics, as can be noticed in the Table 1, show extreme values of the flow resistance, hereby it is decided comparing it with a fabric that shows a mid flow resistance value inside the set of tested fabrics, and this is fabric T7. Figure

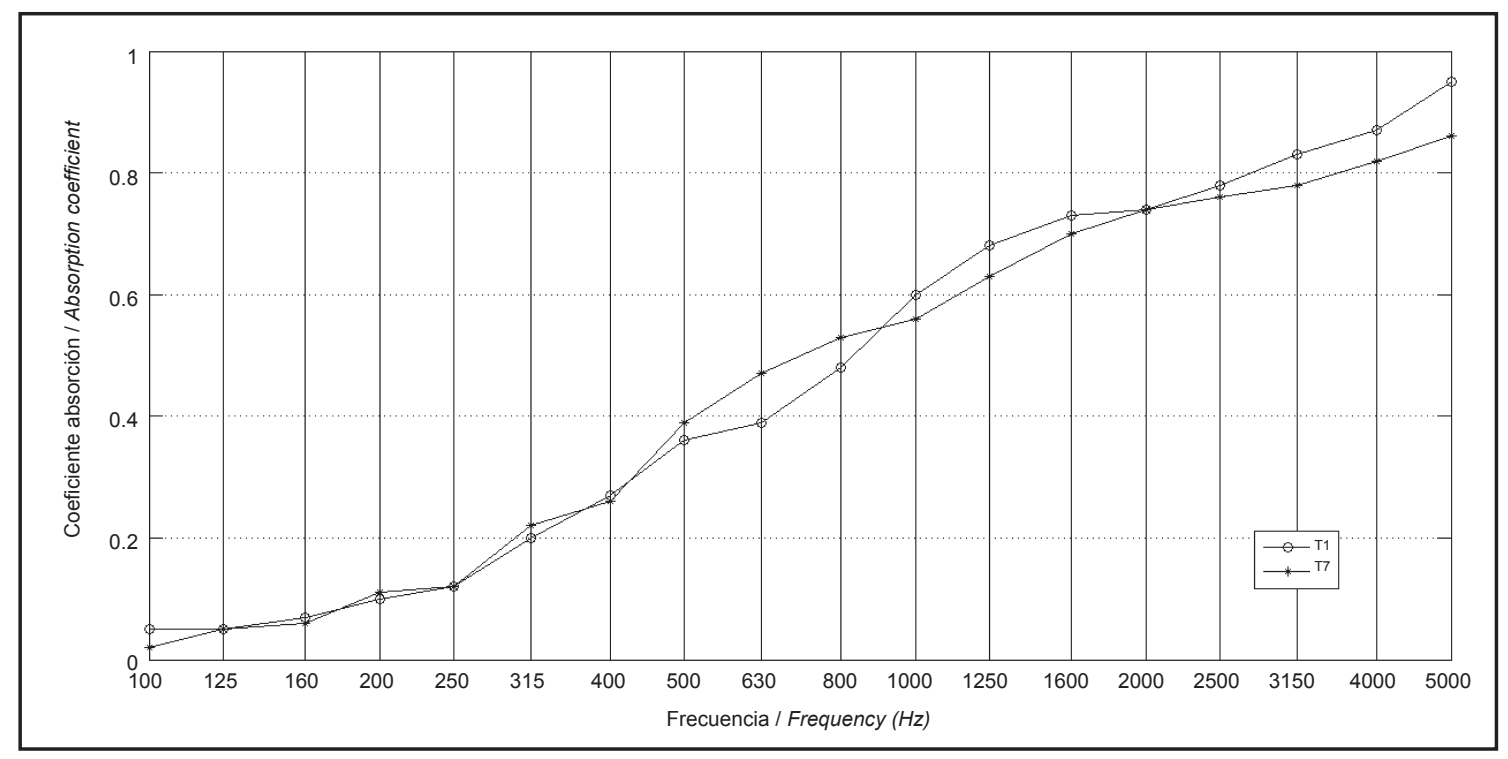

Figura 9. Comparativa de tela T7 con tela T1. Plenum de $8,5 \mathrm{~cm}$ y $100 \%$ de vuelo. Figure 9. Comparison of the T7 with T1. Plenum of $8.5 \mathrm{~cm}$ and $100 \%$ fullness. 
telas ensayadas, esta es, la tela T7. En la Figura 9 se muestran los resultados comparando (T1) y (T7) con un plenum de $8,5 \mathrm{~cm}$ y $100 \%$ de vuelo. Puede observarse cómo los resultados son bastante similares. En la Figura 10 , se muestran resultados para las tres telas, con un plenum de $14,5 \mathrm{~cm}$ y $100 \%$ de vuelo. Aunque los resultados son similares, al aumentar el plenum se puede observar cómo la absorción acústica empeora algo en alta frecuencia y mejora algo en frecuencias medias.
9 presents the results comparing ( $T 1$ ) and (T7) with a plenum of $8.5 \mathrm{~cm}$ and $100 \%$ fullness, where it can be seen that the results are quite similar. Figure 10 exposes the results for the three fabrics with a plenum $14.5 \mathrm{~cm}$ and $100 \%$ fullness. Although the results are similar, with the increasing plenum it can be seen how the acoustic absorption becomes mildly worse at high frequency and improves at the midrange.

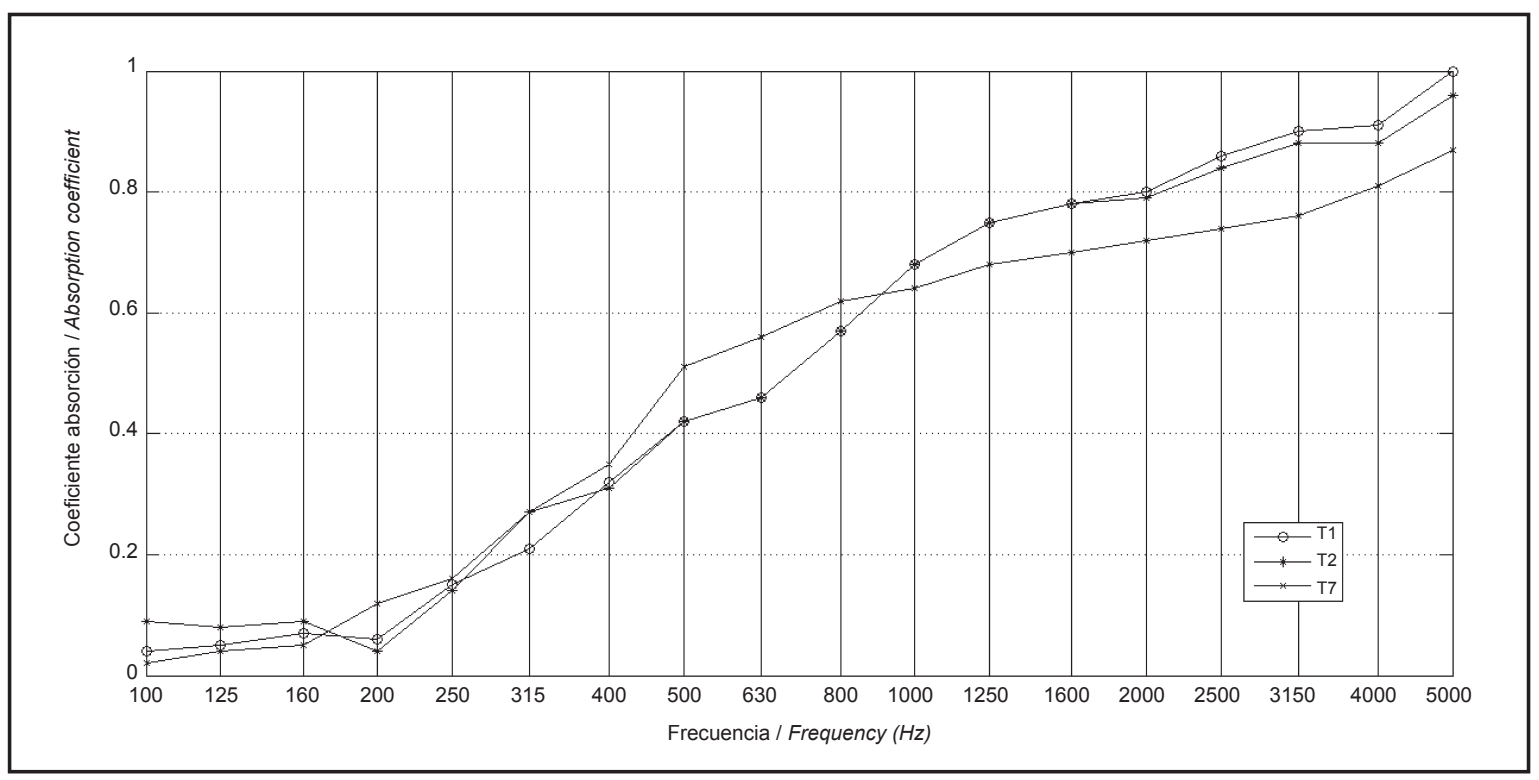

Figura 10. Comparativa de las tres telas con plenum de $14,5 \mathrm{~cm}$ y $100 \%$ de vuelo.

Figure 10. Comparison of the three fabrics with $14.5 \mathrm{~cm}$ of plenum and $100 \%$ fullness.

En la Tabla 2 se muestran los valores del valor medio del coeficiente de absorción desde $400 \mathrm{~Hz}$ hasta $2.500 \mathrm{~Hz}$, redondeado a múltiplos de 0,05 . Este dato es el que se utiliza para el Código Técnico de la Edificación (4). También se muestran los valores del coeficiente de absorción ponderado, $\alpha_{\mathrm{w}}$. El procedimiento para obtener este valor a partir de los valores de por frecuencias en cámara reverberante se detalla en (28). Este valor sirve para evaluar el grado de absorción proporcionado por un material.
Table 2 illustrates the average values of the absorption coefficient from $400 \mathrm{~Hz}$ to $2500 \mathrm{~Hz}$, rounded to multiples of 0.05. This data used for the Technical Building Code (3). They are also shown the values of the weight absorption coefficient, $\alpha_{w}$. The procedure to obtaining this value from data obtained in reverberation chamber is detailed in (28). This value is useful to evaluate the absorption grade provided by a material.

Tabla 2 / Table 2

Coeficiente de absorción medio y $\alpha \mathrm{w}$ de T1 (a), T2 (b) y T7 (c).

Average acoustic absorption coefficient and $\alpha w T 1$ (a), T2 (b) and T7 (c).

(a)

\begin{tabular}{|c|c|c|c|c|}
\hline Textil / Textile & Plenum / Plenum (cm) & Fruncido / Fullness (\%) & $\begin{array}{l}\text { Alpha medio / } \\
\text { Average alpha } \\
(400 \mathrm{~Hz}-2500 \mathrm{~Hz})\end{array}$ & $\begin{array}{c}\alpha_{w} / \alpha_{w} \\
\text { UNE EN ISO } 140 \\
11654: 1998\end{array}$ \\
\hline \multirow{8}{*}{ T1 } & \multirow{4}{*}{8.5} & 0 & 0.45 & 0,25 \\
\hline & & 100 & 0.55 & 0.35 \\
\hline & & 150 & 0.60 & 0.45 \\
\hline & & 200 & 0.55 & 0.45 \\
\hline & \multirow{4}{*}{14.5} & 0 & 0.45 & 0.30 \\
\hline & & 100 & 0.65 & 0.40 \\
\hline & & 150 & 0.65 & 0.45 \\
\hline & & 200 & 0.50 & 0.40 \\
\hline
\end{tabular}


(b)

\begin{tabular}{|c|c|c|c|c|}
\hline Textil / Textile & Plenum / Plenum $(\mathrm{cm})$ & Fruncido / Fullness (\%) & $\begin{array}{l}\text { Alpha medio I } \\
\text { Average alpha } \\
(400 \mathrm{~Hz}-2500 \mathrm{~Hz})\end{array}$ & $\begin{array}{c}\alpha_{w} / \alpha_{w} \\
\text { UNE EN ISO } 140 \\
11654: 1998\end{array}$ \\
\hline \multirow{8}{*}{ T2 } & \multirow{4}{*}{14.5} & 0 & 0.50 & 0.35 \\
\hline & & 100 & 0.60 & 0.40 \\
\hline & & 150 & 0.60 & 0.45 \\
\hline & & 200 & 0.75 & 0.40 \\
\hline & \multirow{4}{*}{20.5} & 0 & 0.50 & 0.35 \\
\hline & & 100 & 0.65 & 0.45 \\
\hline & & 150 & 0.55 & 0.50 \\
\hline & & 200 & 0.75 & 0.40 \\
\hline
\end{tabular}

(c)

\begin{tabular}{|c|c|c|c|c|}
\hline \multirow{2}{*}{ Textil / Textile } & Plenum / Plenum (cm) & Fruncido / Fullness (\%) & $\begin{array}{c}\text { Alpha medio / } \\
\text { Average alpha } \\
\mathbf{( 4 0 0 H z - 2 5 0 0 H z )}\end{array}$ & $\begin{array}{c}\boldsymbol{\alpha}_{\mathrm{w}} / \boldsymbol{\alpha}_{w} \\
\text { UNE EN ISO 140 } \\
\mathbf{1 1 6 5 4 : 1 9 9 8}\end{array}$ \\
\hline \multirow{2}{*}{$\mathrm{T} 7$} & 8.5 & 100 & 0.55 & 0.40 \\
\cline { 2 - 5 } & 14.5 & 100 & 0.60 & 0.45 \\
\hline
\end{tabular}

\section{CONCLUSIONES}

A partir de los resultados que se muestran en este trabajo, se pueden considerar varias conclusiones. En primer lugar puede verse cómo una cortina con un plenum detrás y con vuelo o no, tiene una curva de absorción acústica creciente con la frecuencia. Esto es de interés puesto que puede utilizarse para acondicionamiento acústico (9-11).

Si se analizan los datos de la tela 1 con un plenum determinado, se observa cómo el coeficiente de absorción tiene tendencia a aumentar con el aumento del vuelo. Este aumento de la absorción se estabiliza al llegar al 100\% de vuelo. Esto sucede con las distintas posiciones de plenum ensayadas y también con la tela 2 . Con esto se puede concluir que con el $100 \%$ de vuelo se consigue un aumento eficiente de la absorción, y que a partir de este valor no es eficiente aumentar el vuelo.

Si se comparan diferentes telas fijando un vuelo de $0 \%$ o de $100 \%$ con el mismo plenum, también se observa que los resultados son similares aunque las telas no tengan el mismo espesor, densidad o valor de resistencia al flujo. Esto puede ser debido a que, una vez superado el valor umbral de resistividad al flujo de $100 \mathrm{kPas} / \mathrm{m}^{2}$ las telas, dentro de un rango de espesor y densidad, tienen un comportamiento similar con un plenum cercano a la pared. Si se aleja la cortina de la pared (aumento de plenum) empieza a notarse cambios, con aumentos de la absorción acústica a más baja frecuencia. Es destacable cómo los valores medios de absorción apenas cambian.

En el caso de vuelos superiores al $100 \%$, ya no parece seguir una regla y cada tela tiene un comportamiento diferente.

\section{CONCLUSIONS}

From the results presented in this study, several conclusions can be drawn. Firstly, it can be seen that a curtain with a back plenum and with or without fullness, has an acoustic absorption curve with increasing frequency. This is interesting because it can be used for acoustic conditioning (9-11).

If the data on textile 1 is analyzed with a particular plenum, it can be observed how the absorption coefficient tends to increase with the fullness increasing to $100 \%$, where it stabilizes or increases insignificantly. The growth of the absorption stabilizes at $100 \%$ of fullness. It is the same for the different air plenums tested and the fabric 2. Finally, it can be concluded that with the $100 \%$ of curtain fullness, an efficient absorption increase can be obtained; on the other hand, higher fullness values are not efficient.

When comparing different textiles with a fullness fixed of $0 \%$ or $100 \%$ with the same plenum, it is also is observed that the results are similar, although they have different fabrics thickness, density or flow resistivity. This may be because when the threshold value of the flow resistivity $100 \mathrm{kPas} / \mathrm{m}^{2}$ is exceeded, textiles, within a range of thickness and density, display similar behavior to a plenum near the wall. If a curtain away from the wall (increased plenum) begins to produce changes, producing the acoustic absorption increases at lower frequency. It is remarkable how the absorption values hardly changed.

In the case of fullness higher than $100 \%$, there seems to be no strict rule and each fabric displays a different behavior. 
Por último, según estos datos, se podría afirmar que, si se elige una tela de características de espesor, densidad y resistividad al flujo similar a los datos presentados, es muy probable que los resultados del coeficiente de absorción y sobre todo, del coeficiente de absorción medio, sean muy parecidos a los obtenidos en este trabajo.

Como futuras líneas de trabajo se propone ampliar el estudio a más telas, buscando una correlación más clara en los datos de ensayo, e incluso, colocar más de una tela, combinando así el efecto de diferentes cortinas.
Finally, according to this data, it could be argued that if a fabric is chosen with a thickness, density and flow resistivity characteristics similar to the data presented, it is likely that the results of the absorption coefficient and especially the average absorption coefficient will be similar to those obtained in this work.

For future works it is proposed to extend the study to a greater number of textiles looking for a clearer correlation in the test data and use more than one fabric, combining the effect of different curtains.

\section{BIBLIOGRAFÍA / BIBLIOGRPHY}

(1) World Health Organization (WHO), Guidelines for Community Noise. http://www.euro.who.int/en/what-we-do/health-topics/environmental-health, Ginebra, 1999.

(2) Real Decreto 1371/2007, de 19 de octubre, por el que se aprueba el Documento Básico "DB-HR Protección frente al ruido" del Código Técnico de la Edificación y se modifica el Real Decreto 314/2006, de 17 de marzo, por el que se aprueba el Código Técnico de la Edificación (BOE 23-octubre-2007). Corrección de errores y erratas de la orden VIV/984/2009, de 15 de abril, por la que se modifican determinados documentos básicos del Código Técnico de la Edificación, aprobados por el Real Decreto 314/2006, de 17 de marzo, y el Real Decreto 1371/2007, de 19 de octubre (BOE 23-septiembre-2009).

(3) Catálogo de elementos de construcción. Código Técnico de la Edificación. www.codigotecnico.org

(4) Navacerrada, M. A.; Díaz, C.; Pedrero, A.; García, L.E.: "Acoustic properties of aluminium foams". Mater. Construcc., vol. 58, no 291 (2008), pp. 85-98. http://dx.doi.org/10.3989/mc.2008.v58.i291.109

(5) Ramis J.; Alba J.; del Rey R.; Escuder E.; Sanchís V.: "Acoustic properties of aluminium foams", Mater. Construcc., vol. 60, no 299, (2010), pp. 133-143. http://dx.doi.org/10.3989/mc.2010.50809

(6) del Rey R.; Alba J.; Ramis J.; Sanchís VJ.: "New absorbent acoustic materials from plastic bottle remnants". Mater. Construcc., vol. 61, no 304 (2011), pp. 547-558. http://dx.doi.org/10.3989/mc.2011.59610

(7) del Rey, R.; Alba, J.; Arenas, J. P.; Sanchís, V.J.:"An empirical modelling of porous sound absorbing materials made of recycled foam". App.l Acoust. vol. 73, no 6-7 (2012), pp. 604-609. http://dx.doi.org/10.1016/j.apacoust.2011.12.009

(8) Díaz, C.; Jiménez, M.; Navacerrada, M.A.; Pedrero, A;: "Acoustic properties of reed panels". Mater. Construcc., vol. 62 , no 305 (2012), pp. 55-66. http://dx.doi.org/10.3989/mc.2010.60510

(9) Lawrence A.; Architectural Acoustics. Applied Science Publisher, Ltd, Barking, Essex, Inglaterra,(1970).

(10) Cavanaugh. W,J,; Wilkes, J.A.: Architectural acoustics: principles and practice. John Wiley \& Sons, New York (1998).

(11) Egan MD. Architectural Acoustics. J Ross Publishing (2007).

(12) Egan, M.D.; Quirt, J.D.; Rousseau, M.Z.: "Architectural Acoustics". J Acoust Soc Am, vol. 86, no 2, 852 (1989). http://dx.doi. org/10.1121/1.398174

(13) Houtsma, A.J.M.; Martin, H.J.; Hak, C.C.J.M.; van Donselaar, C.J.: "Measuring the effectiveness of specia.I acoustic provisions in a concert hall". J Acoust Soc Am, vol. 100, no 4: 2803 (1996). http://dx.doi.org/10.1121/1.416542

(14) Peutz, V.M,A.: "Sound Absorption of Curtains". J Acoust Soc Am, vol. 48, no 80 (1970).

(15) Pirn, R.: "Some objective and subjective aspects of three acoustically variable halls" App.l Acoust, vol. 35, n03 (1992), pp. 221-

231. http://dx.doi.org/10.1016/0003-682X(92)90041-P

(16) Yamada, G.:, Kobayashi, Y.; Hamaya, H.: "Transient response of a hanging curtain". J Sound Vib, vol. 130, n 2 (1989), pp. 223-235. http://dx.doi.org/10.1016/0022-460X(89)90551-8

(17) Soedel, W, Zadoks, R.I.; Alfred, J.R.: "Natural frequencies and modes of hanging nets or curtains". J Sound Vib, vol. 103, no 4 (1985), pp. 499-507. http://dx.doi.org/10.1016/S0022-460X(85)80018-3

(18) ISO 10534-2.Acústica. Determinación acústica del coeficiente de absorción sonora en tubos de impedancia. Parte 2: Método de la función de transferencia. International Organization for Standardization (1998).

(19) Chen, Y.; Jiang, N.: "Carbonized and activated non-wovens as high-performance acoustic materials". Text Res J, vol. 77, n 10 (2007), pp. 785-791.

(20) Yang, S.; Yu, W.; Pan, N.;"Investigation of Sound Absorbing Behavior of Fiber Assemblies", TextRes J, vol. 81, n07 (2011), pp. 673-682.

(21) Pieren, R.:" Sound absorption modeling of thin woven fabrics backed by an air cavity". Text Res J, vol. 82, no 9, (2012), pp. 864-874. 
R. del Rey et al.

(22) UNE-EN ISO 354:2004. Acústica. Medición de la absorción acústica en una cámara reverberante (ISO 354:2003).

(23) UNE-EN 13773:2003 Textiles y productos textiles. Comportamiento al fuego. Cortinas y cortinajes. Esquema de clasificación.

(24) UNE-EN 29053.1994. Acústica. Materiales para aplicaciones acústicas. Determinación de la resistencia al flujo de aire (ISO9053:1991).

(25) Ingard, K. U.; Dear, T. A.: "Measurement of Acoustic Flow Resistance". Journal of sound and Vibration, 103 (1985), pp. 567572.

(26) Carrión, A.: Diseño acústico de espacios arquitectónicos. Ediciones UPC. 1998.

(27) Ramis, J,; Alba, J.; Martínez, J.; Redondo, J.: "The uncertainty in absorption coefficients measured in reverberant chambers: A case study". J Noise \& Vibration Worldwide, vol. 36, no 1, (2005), pp. 7-12.

(28) UNE-EN ISO 11654:1998. Acústica. Absorbentes acústicos para su utilización en edificios. Evaluación de la absorción acústica (ISO 11654:1997). 